\title{
Trace elements in Libyan Cereals: Estimation of Daily Intakes of Cobalt, Chromium, Molybdenum and Selenium
}

\author{
Mokhtar M Abobaker Basher M Mahara and Shaban W Al-Rmalli* \\ Chemistry Department, Faculty of Sciences, Tripoli University, Tripoli, Libya. \\ *Corresponding author: SW Al-RmalliE-Mail: shwalrmalli@gmail.com
}

\begin{abstract}
Elements such as cobalt (Co), chromium (Cr), molybdenum (Mo) and selenium (Se) are essential elements for human being, these elements occur in cereals which are important food in Libyan population diet. The present study was carried out to determine concentrations of trace metals and evaluate the potential health risk of metal to humans via consumption of cereals. Cereal samples from Libya were digested using nitric acid and by microwave digester then trace elements concentrations in cereal samples were determined by using ICPMS instrument. Daily intakes of $\mathrm{Co}, \mathrm{Cr}, \mathrm{Mo}$ and Se from all cereals consumption were 19.4, 93, 261 and 34.7 $\mu \mathrm{g} /$ day, respectively. The RDA was used to estimate daily intakes of these elements. Daily intake of Mo exceeded of RDA by 2 fold. More investigations should be done for daily intake of trace elements in Libyan population for cereals and other food consumption.
\end{abstract}

Keywords: Libya, cereals, trace elements, ICP-MS, daily intakes

\section{Introduction}

Cobalt, chromium, molybdenum and selenium are essential elements for human being. These days determination of trace elements in food becomes very important to estimate human intake of these elements which illustrates both deficiencies and toxicity for humans.

Cobalt is an integral component of the vitamin B-12 molecule. It is required in the creation of red blood cells and in preventing anaemia. However, an excessive intake of cobalt may cause the overproduction of red blood cells [1]. Chromium (III) occurs naturally in environment and it is essential nutrient required by the human body functions such as sugar and fat metabolism [2]. It is effective to the management of diabetes and it is a cofactor with insulin, $\mathrm{Cr}$ (III) and its compounds are not considered a health hazard [3]. While the toxicity and carcinogenic properties of $\mathrm{Cr}(\mathrm{VI})$ have been reported for long time exposure.

Molybdenum participated as a cofactor for a limited number of enzymes in humans and in all mammalian molybdoenzymes, functional Mo is present as an organic component called molybdopterin [4]. It is found in many different in food including cereals, however, little is known about the bioavailability of Mo from different food sources, but one study among men and another among women demonstrated that it is less efficiently absorbed from soy, which contains relatively high amounts [5]. Information on dietary intake of Mo is limited because of lack of a simple, reliable analytical method for determining Mo. One U.S. study reported intakes ranging from 120 to $240 \mu \mathrm{g} /$ day, with an average intake of $180 \mu \mathrm{g} / \mathrm{day}$ [6]. Data from the Total Diet Study indicate an average molybdenum intake of $76 \mu \mathrm{g} /$ day for women and $109 \mu \mathrm{g} /$ day for men [7]. Furthermore, the minimum requirement of Mo was estimated to be $25 \mu \mathrm{g} /$ day, approximately [8].

Selenium is an essential element that has many functions in the human body. It has been reported that Se has preventive potency against Keshan disease and has important antioxidant activities [8-10]. It has been suggested that Se protects the body against As toxicity [11,12] and can have a positive role in the immune system functions [13]. The Recommended Dietary Allowance (RDA) for Se has been estimated to be 55 and 70 $\mu \mathrm{g} / \mathrm{day}$ for women and men respectively (dependent upon average body weight) [14]. It is known that selenium levels range from low to high levels in different foods, such as Brazil nuts, cucumber, grain, mushroom, shellfish and wheat [15]. In addition, it has been recognised that selenium plays a role in the decrease of arsenic toxicity owing to the two elements behaving as metabolic antipodes [16]. In Chine, deficiency of selenium was initially established, with the disease believed to be instigated through low Se levels in soil in Keshan (China). Accordingly, there was a low intake of Se, sometimes lower than $10 \mu \mathrm{gSe} / \mathrm{day}$ [17]. Moreover, toxicity of $\mathrm{Se}$ is also linked with thyroid hormones syntheses. A Libya study has estimated daily intake of Se in food [18].

Many techniques are used to measure trace elements, however, these days ICP-MS is widely used to determine trace elements in environmental samples because it has high precision compared with many other techniques [19]. The objectives of the present work are to determine $\mathrm{Co}, \mathrm{Cr}$, Mo, and Se in Libyan cereal using microwave digestion method and ICP-MS technique for measurement. The daily intakes of these elements are estimated in the current study. 


\subsection{Sample collection}

\section{Materials and methods}

Five types of cereals which are widely consumed in Libya were analysed. Cereals including wheat, Barley, rice and corn, were purchased from Libya during the months of August 2009 and June 2010. The products analysed in this study were mainly of Libyan origin except rice. Cereals samples were treated before digestion, ground using a coffee grinder and then kept for analysis.

\subsection{Sample digestion}

Cereals samples were digested using a microwave digester. A dry ground weight $(0.3-0.5 \mathrm{~g})$ of sample was mixed with $4 \mathrm{ml}$ of $70 \%$ nitric acid $\left(\mathrm{HNO}_{3}\right)$ (Romil-UpA ${ }^{\mathrm{TM}}$, Romil Ltd., Cambridge, UK) and $2 \mathrm{ml}$ of hydrogen peroxide $\left(\mathrm{H}_{2} \mathrm{O}_{2}\right)$ and then microwave digested for 40 minutes at a total pressure of 20 bars and a maximum temperature of $170^{\circ} \mathrm{C}(\mathrm{CEM}$, Microwave digestion MAR Xpress, Matthews, NC, USA). The digested solutions were evaporated to dryness and then diluted to $25 \mathrm{ml}$ in volumetric flasks with ultra-pure water (Romil-UpSTM, Romil Ltd., Cambridge, UK) prior to analysis.

\subsection{Determination of toxic elements concentrations}

Concentrations of trace elements ( $\mathrm{Co}, \mathrm{Cr}$, Mo and $\mathrm{Se}$ ) in the digested samples were determined by inductively coupled plasma mass spectrometry (ICP-MS). A Thermo-Fisher Scientific X-SeriesII instrument equipped with CCTED (collision cell technology with energy discrimination).

\subsection{Quality control and standard reference material}

In this study, all the sample masses were measured to an accuracy of $\pm 0.1 \mathrm{mg}$. Elemental concentrations obtained by the ICP-MS technique were evaluated using certified reference materials and were found to be in good agreement with the certified values. The analytical procedure and the reliability of the digestion process of the samples were validated by analysis of different types of standard reference materials (see Table 1). The average recoveries of references material ranged from 84 to $103 \%$ for all measurement runs.

Table 1: Rice flour (NIES No. 10-b) SRM, concentrations of elements $(\mu \mathrm{g} / \mathrm{kg})$

\begin{tabular}{|c|c|c|c|}
\hline Element & Certified value & Found value & Recovery \% \\
\hline Co & 20 & 19.2 & 96 \\
$\mathrm{Cr}$ & 220 & 184.5 & 84 \\
$\mathrm{Mo}$ & $420 \pm 50$ & $435 \pm 38$ & 103 \\
$\mathrm{Se}$ & 20 & 18 & 90 \\
\hline
\end{tabular}

\section{Results and Discussion}

Results of measurement of $\mathrm{Cr}, \mathrm{Co}$, Mo and Se elements in different Libyan cereals are presented as a mean $\pm \mathrm{SD}(\mu \mathrm{g} / \mathrm{kg})$ in figures (1-4). Cereal species covered in this investigation are wheat, rice, barley and corn. The highest concentrations of $\mathrm{Cr}$ and Mo were found in wheat (601 and $2309 \mu \mathrm{g} / \mathrm{kg})$, respectively. However, the mean concentrations of $\mathrm{Cr}$ and Mo in cereals $(\mu \mathrm{g} / \mathrm{kg})$ were wheat $(174,366)$ barley $(254,913)$ and rice $(50$, $955)$, respectively. For wheat grain, the mean concentrations $( \pm \mathrm{SD})$ were $38 \pm 17 \mu \mathrm{g} / \mathrm{kg}$ of Co, $174 \pm 144 \mu \mathrm{g} / \mathrm{kg}$ of $\mathrm{Cr}, 366 \pm 91 \mu \mathrm{g} / \mathrm{kg}$ of Mo and $62 \pm 41 \mathrm{mg} / \mathrm{kg}$ of Se (figures 1-4).

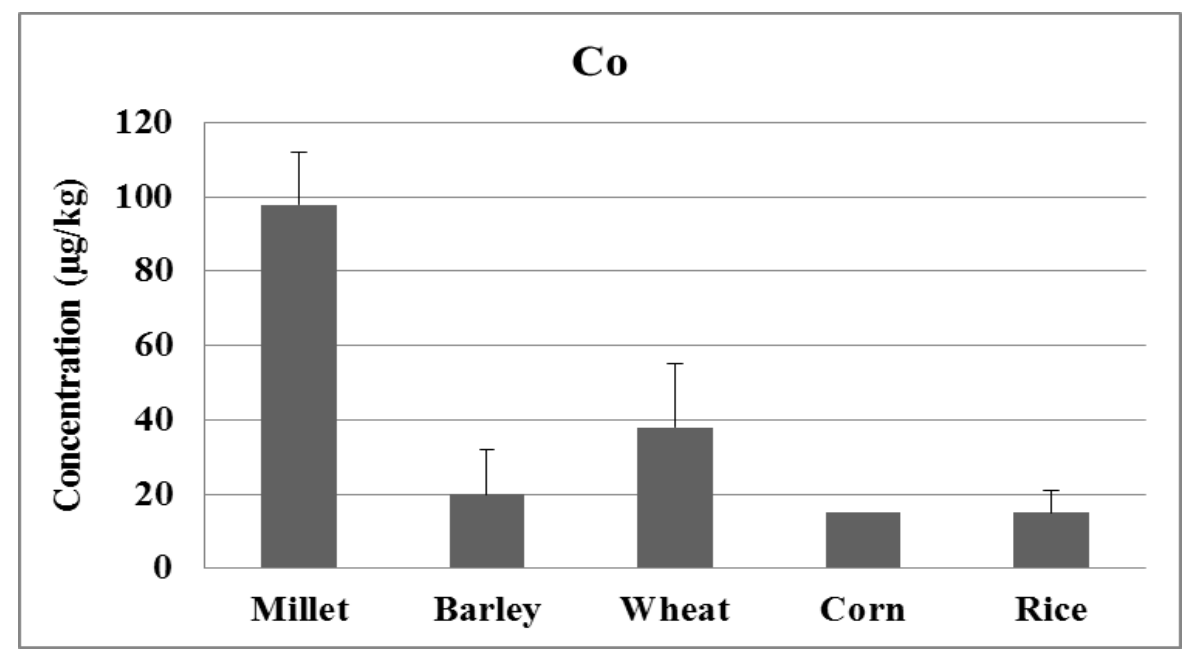

Figure 1: Concentrations ( $\mu \mathrm{g} / \mathrm{kg}$ ) of cobalt in Libyan Cereals (as mean and SD). 


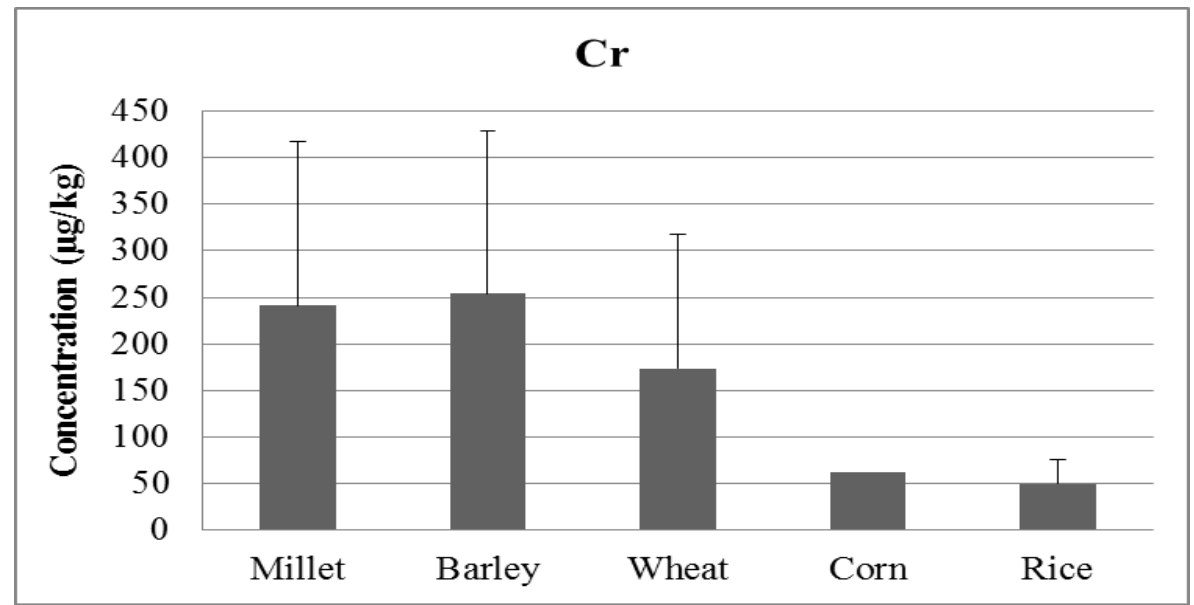

Figure 2: Concentrations $(\mu \mathrm{g} / \mathrm{kg})$ of chromium in Libyan Cereals (as mean and SD).

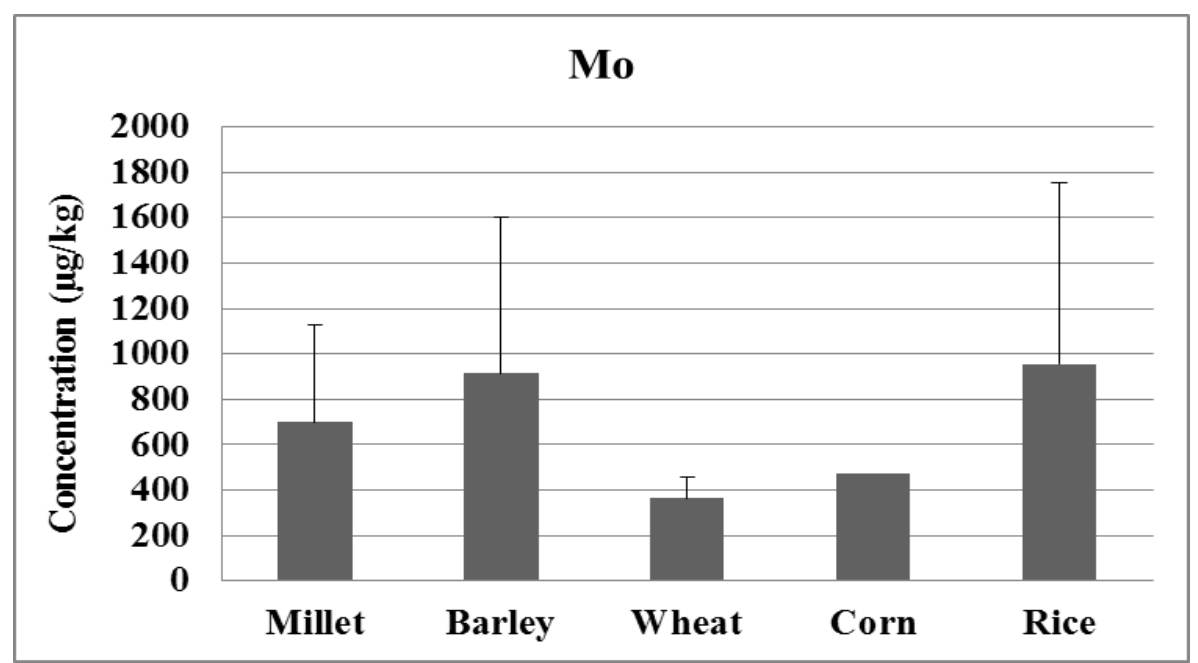

Figure 3: Concentrations $(\mu \mathrm{g} / \mathrm{kg}$ ) of Molybdenum in Libyan Cereals (as mean and SD).

On other hands the lowest concentrations of Co and Se elements among cereals were detected in rice grain (figures 1 and 4). Barley is another cereal that consume from Libyan population, with the mean concentrations of Co, Cr, Mo and Se $( \pm \mathrm{SD})$ were $20 \pm 12 \mu \mathrm{g} / \mathrm{kg}, 254 \pm 174 \mu \mathrm{g} / \mathrm{kg}, 913 \pm 688 \mu \mathrm{g} / \mathrm{kg}$ and $87 \pm 36 \mu \mathrm{g} / \mathrm{kg}$, respectively (figures 1-4).

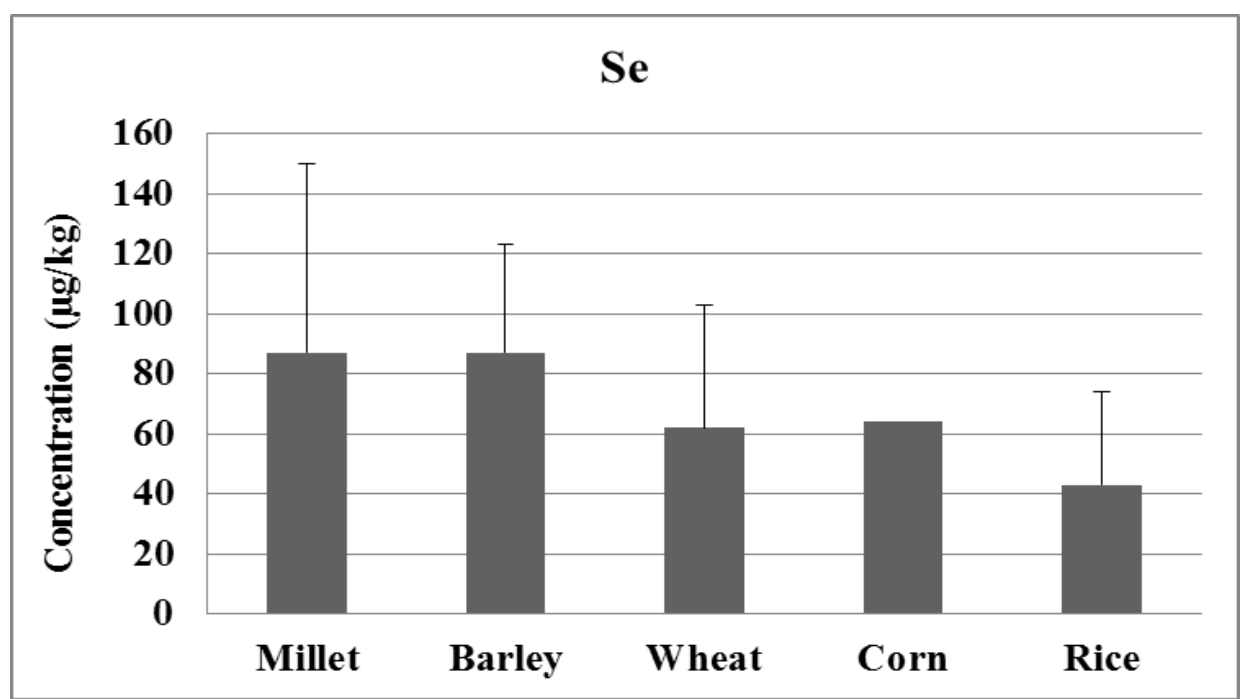

Figure 4: Concentrations $(\mu \mathrm{g} / \mathrm{kg}$ ) of selenium in Libyan Cereals (as mean and SD). 
Table 2 shows that daily intake (DIs) of Cr, Co, Mo, and Se elements (mean concentrations of elements were used). Generally, consumption of wheat can result in high daily intakes of these elements compared to consumption for someone consuming $486 \mathrm{~g}$ of wheat (the weight quantity was adapted from FAOSTAT) [20]. The daily intakes of wheat were (Cr $81.45 \mu \mathrm{g} /$ day), (Co $17.79 \mu \mathrm{g} / \mathrm{day}$ ), (Mo $171.32 \mu \mathrm{g} / \mathrm{day}$ ) and (Se 29.02 $\mu \mathrm{g} /$ day), however, intakes of these elements in Libya population consumption of $60.3 \mathrm{~g}$ of rice per day can reach the daily intakes of Mo to be $(57.59 \mu \mathrm{g} /$ day $)$ and $\mathrm{Cr}(3.02 \mu \mathrm{g} /$ day $)$. Otherwise, daily intakes of Se and Co were 2.59 and $0.9 \mu \mathrm{g} /$ day, respectively (table 2 ).

Table 2: Daily intake ${ }^{\mathrm{a}}(\mu \mathrm{g} /$ day) in cereals for Libyan population.

\begin{tabular}{|l|c|c|c|c|c|}
\hline Elements & $\begin{array}{c}\text { Wheat }(\mathrm{n}=4) \\
(468 \mathrm{~g} / \text { capita/day })^{\mathrm{b}}\end{array}$ & $\begin{array}{c}\text { Barley }(\mathrm{n}=6) \\
(33.6 \mathrm{~g} / \text { capita/day })\end{array}$ & $\begin{array}{c}\text { Rice (n=4) } \\
(60.3 \mathrm{~g} / \text { capita/day })\end{array}$ & $\begin{array}{c}\text { Corn } \begin{array}{c}(\mathrm{n}=1) \\
(2.8 \mathrm{~g} / \text { capita/day })\end{array} \\
\text { cereals }\end{array}$ \\
\hline $\mathrm{Co}$ & 17.79 & 0.67 & 0.90 & 0.04 & 19.41 \\
$\mathrm{Cr}$ & 81.45 & 8.53 & 3.02 & 0.18 \\
$\mathrm{Mo}$ & 171.32 & 30.68 & 57.59 & 1.33 \\
$\mathrm{Se}$ & 29.02 & 2.92 & 2.59 & 0.18 \\
\hline
\end{tabular}

${ }^{a}$ the total mean concentrations were used to calculate daily intake. ${ }^{b}$ Food supply quantity (g/capita/day) was adapted from FAOSTAT [20].

In barley grain, daily intakes of Mo was (30.68 $\mu \mathrm{g} /$ day) and $\mathrm{Cr}(8.53 \mu \mathrm{g} / \mathrm{day})$, however daily intakes of Co and Se were 0.67 and $2.92 \mu \mathrm{g} /$ day, respectively (Table 2). Corn grain has the lowest daily intakes of trace elements because it has low consumption by Libyan population $(2.8 \mathrm{~g} / \mathrm{day})$. Wheat can be the major source of daily intakes of $\mathrm{Cr}, \mathrm{Co}$, Mo, Se and other; however, rice can be the second cereal source of these elements.

The Recommended Daily Allowance (RDA) scale was used in the current study (see Table 3). From RDA estimation, Mo intake from wheat was exceeded the RDA by 2 fold (228.4\%), this may demonstrate that Libyan population consume high content of Mo. Rice also can provided a high quantity of Mo by consume just $60.3 \mathrm{~g}$ of rice per day, RDA of rice consumption was estimated to be $76.8 \%$ for Mo. Particularly, the total RDA of Mo by cereals consumption in this study was $347.9 \%$ (3.5 fold). Concentration of selenium in wheat showed high intake with RDA (83\%), however, Cr was providing 67.9\% of RDA form wheat consumption. On the other hands, the PMTDI scale was used for estimating daily intakes of Co from cereals consumption, 59.3\% was estimated from only wheat consumption, while for all type of cereals the PMTDI was $64.7 \%$. High intake of wheat is clearly a major factor for elevated exposure to Mo and Co in Libyan population. Our results showed that wheat and rice were the mean source of $\mathrm{Co}, \mathrm{Cr}$, Mo, and Se elements in Libya compared with other cereals. Cereals are a staple food for Libyan population and it can be the main source of micronutrients for them. The present study focused on concentration of $\mathrm{Co}, \mathrm{Cr}$, Mo and Se in Libyan wheat and barley originating mainly from Libyan and the others rice and corn which are imported from outside.

Table 3: The RDA\% of Libyan cereals ${ }^{\text {a }}$

\begin{tabular}{|l|c|c|c|c|}
\hline Cereals & Co $^{\text {b }}$ & Cr & Mo & Se \\
\hline Wheat & 59.30 & 67.88 & $\mathbf{2 2 8 . 4 3}$ & 82.91 \\
Barley & 2.23 & 7.11 & 40.91 & 8.34 \\
Rice & 3.00 & 2.52 & 76.79 & 7.40 \\
Corn & 0.13 & 0.15 & 1.77 & 0.51 \\
All cereals & 64.66 & 77.65 & $\mathbf{3 4 7 . 8 9}$ & 99.17 \\
\hline
\end{tabular}

a the RDA: The Recommended Daily Allowance [21]. ${ }^{\mathrm{b}}$ the PMTDI was used: The Provisional Maximum Tolerable Daily Intake, assuming the body weight for adult is 70kg [22].

Very little information is available in the literature about the trace elements content of Libyan cereals. The literature review reveals that these are a gap in knowledge on the essential elements in Libyan cereal. Therefore, this study tried to fill this gap by determination of trace elements. Some studies from other countries have been reported concentration of trace elements including $\mathrm{Co}, \mathrm{Cr}$, Mo and Se elements in cereals and some of them have estimated total daily intake of trace elements for foods including cereal [23-25]. Selected cereals including wheat and barley from Ethiopia were investigated [23]. Concentration of $\mathrm{Cr}$, and Co in Ethiopia study were 290 and $140 \mu \mathrm{g} / \mathrm{kg}$ for barley and 430 and $350 \mu \mathrm{g} / \mathrm{kg}$ for wheat, respectively [23]. Compared to our results, the level of elements in Ethiopian study higher than that in the present study (figures 1-4). In Indian study Co levels in both wheat and barley were measured [24]. Concentrations of Co in Indian cereals were (mean \pm SD) $20 \pm 10$ and $18 \pm 5$ for wheat and barley, respectively. These data were very similar to our results for Co content in both wheat and barley. Latvia study has reported $\mathrm{Cr}$ content in wheat and barley [25], Cr content was ranged in wheat 53-295 $\mu \mathrm{g} / \mathrm{kg}$; however, in barley was $21-921 \mu \mathrm{g} / \mathrm{kg}$. These data was also similar to that obtained from the present study.

El-Ghawi et. al. (2005) has reported that daily intake of Se in Libyan population for all food ranged between 13 to $44 \mu \mathrm{g} /$ day [18]. However, here in the current study, the data showed daily intake of Se from cereal consumption can be exposed $34 \mu \mathrm{g} /$ day. El-Ghawi et. al. study [18] appearance that Libyan population 
has Se deficiency. From our study we can say more investigations should be done to have good view of Se situation in Libyan population.

From our study, Mo content was higher than RDA by 2 fold. However, the daily intake in the present study exposed that consumption of Libyan cereal does not reach to the risk. Daily intakes of trace elements from consuming cereal in Libya were less than the PMTDI of these elements and no risk was detected from the present study. We concluded that Libyan population dose not expose to high levels of trace elements from cereals consumption however more study should be done for total daily intake of trace elements from consumption of different types of foods and to have complete sight of Libyan situation, also and assess the risk of these trace elements among the Libyan population.

\section{References}

[1]. G. Mangiarotti, C. Canavese, M. Salomone, et al. Hypervitaminosis B12 in maintenance hemodialyse patients receiving massive supplementation of vitamin B12. Int J Artif Organs 9 (1986) 417-420.

[2]. R A Anderson. Chromium and insulin resistance. Nutr Res Rev., 16 (2003) 267-275.

[3]. W T Cefalu \& F B Hu. Role of chromium in human health and in diabetes. Diabetes Care, 27 (2004) $2741-2751$.

[4]. K V Rajagopalan. Molybdenum: An essential trace element in human nutrition. Ann Rev Nutr., 8 (1988) 401-427.

[5]. J R Turnlund, C M Weaver, S K Kim, W R Keyes, Y Gizaw, K H Thompson, G L Peiffer. Molybdenum absorption and utilization in humans from soy and kale intrinsically labeled with stable isotopes of molybdenum. Am J Clin Nutr., 69 (1999) 1217-1223.

[6]. T A Tsongas, R R Meglen, P A Walravens, W R Chappell. Molybdenum in the diet: An estimate of average daily intake in the United States. Am J Clin Nutr., 33 (1980) 1103-1107.

[7]. J A T Pennington and J W Jones. Molybdenum, nickel, cobalt, vanadium, and strontium in total diets. J Am Diet Assoc., 87 (1987) $1644-1650$.

[8]. M.P. Rayman, The importance of selenium to human health, The Lancet 356(9225) (2000) 233-241. doi:10.1016/ S01406736(00)02490-9.

[9]. M.P. Rayman, Selenium and human health, The Lancet 379(9822) (2012) 1256-1268. doi:10.1016/S0140-6736(11) 61452-9.

[10]. U. Tinggi, Selenium: Its role as antioxidant in human health, Environmental Health and Preventive Medicine, 13 (2008) $102-108$. doi:10.1007/s12199-007-0019-4.

[11]. L. Pograjc, V. Stibilj and I. Falnoga, Impact of intensive physical activity on selenium status, Biological Trace Element Research, 145(3) (2012) 291-299. doi:10.1007/s12011-011-9204-9.

[12]. R.A. Sunde and W.G. Hoekstra, Structure, synthesis and function of glutathione-peroxidase, Nutrition Reviews, 38 (1980) $265-273$. doi:10.1111/j.1753-4887.1980.tb05957.x.

[13]. H.J.S. Larsen, Relations between selenium and immunity, Norwegian Journal of Agricultural Sciences Supplement, 11 (1993) 105119 .

[14]. National Academy of Sciences, Trace elements, in: Recommended Dietary Allowances, National Academy Press, Washington, D.C., 1989, pp. 195-246.

[15]. M P. Rayman, H G Infante and M Sargent. Food-chain selenium and human health: spotlight on speciation. British Journal of Nutrition, 100 (2008) 238-253.

[16]. Y.M. Hsueh, Y.F. Ko, Y.K. Huang, H.W. Chen, H.Y. Chiou, Y.L. Huang, Y. Mo-Hsiung and C.J. Chen, Determinants of inorganic arsenic methylation capability among residents of the Lanyang Basin, Taiwan: Arsenic and selenium exposure and alcohol consumption, Toxicology Letters, 137 (2003) 49-63. doi:10.1016/S0378-4274(0-2)00380-6.

[17]. C. Li, Selenium deficiency and endemic heart failure in China: a case study of biogeochemistry for human health, AMBIO, 36 (2007) 90-93.

[18]. U M El-Ghawi, A A Al-Sadeq, M M Bejey, M B Alamin. Determination of selenium in Libyan food items using pseudocyclic instrumental neutron activation analysis. Biological Trace Elements Research, 107 (2005) 61-71.

[19]. P. A. Gallagher, P, J. A. Shoemaker, X. Wei, C. A. Brockhoff-Schwegel and J. T. Creed. Extraction and detection of arsenicals in seaweed via accelerated solvent extraction with ion chromatographic separation and ICP-MS detection, Fresenius Journal of Analytical Chemistry, 369 (2001) 71-80.

[20]. FAOSTAT, Food supply quantity (g/capita/day) for period from 1997 to 2007 was from FAOSTAT site. http://faostat.fao.org/site/368/DesktopDefault.aspx?PageID=368\#ancor Adopted on 8 May 2017

[21]. Food and Nutrition Board, FNB, (2001) of the National Academy of Sciences, Institute of Medicine. Dietary Reference Intakes for Vitamin A, Vitamin K, Arsenic, Boron, Chromium, Copper, Iodine, Iron, Manganese, Molybdenum, Nickel, Silicon, Vanadium, and Zinc. National Academy Press: Washington DC.

[22]. EVM (2003). Safe upper levels for vitamins and minerals. Report of the Expert Group on Vitamins and Minerals. Food Standards Agency, May 2003. ISBN 1- 904026-11-7. http://www.food.gov.uk/multimedia/pdfs/vitmin2003.pdf.

[23]. W A Tegegne. Assessment of Some heavy metals concentration in selected cereals collected from local markets of Ambo city, ( Ethiopia). Journal of cereals and oilseeds, 6(2) (2015) 8-13.

[24]. U C Gupta. Cobalt content of forages and cereals grown on Prince Edward Island. Can. J. Soil Sci., 73 (1993) 1-7.

[25]. I Jakobsone, I Kantane, S Zute, I Jansone and V Bartkevics. Macro-elements and trace elements in cereal grain cultivated in (Latvia), Proceedings of the Latvian academy of sciences, section B, 69 (2015).no.4(697), 152-157. 